\title{
Benoit B. Mandelbrot
}

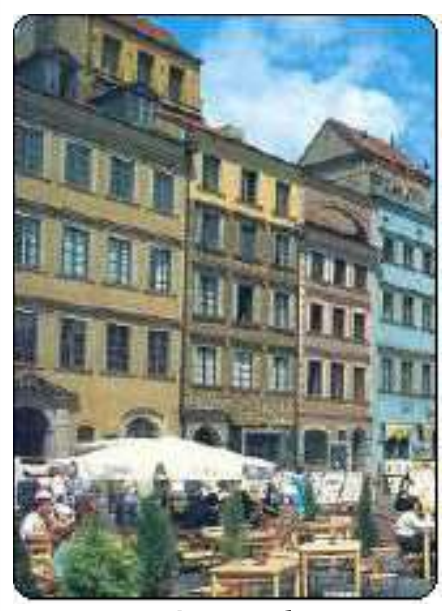

Varsóvia, Polônia

$\mathrm{B}_{\mathrm{e}}$ enoit B. Mandelbrot, um dos mais importantes matemáticos da nossa era nasceu em Varsóvia, na Polônia, em 20 de Novembro de 1924. Varsóvia, que é uma cidade histórica de grande tradição, pertenceu à Prússia e foi sitiada por Napoleão em 1806 e, em 1813, foi incorporada ao Império Russo. Após a II Guerra Mundial a cidade teve que ser reconstruída a partir das suas ruínas devido a brutalidade dos conflitos.

Em Varsóvia, Mandelbrot terminou os seus estudos de nível fundamental, porém, devido aos problemas causados pela segunda guerra mundial, Mandelbrot teve que se mudar para a França, onde terminou os estudos de nível médio na cidade de Tulle (1), uma cidade Concluindo mais tarde a sua formação superior na Ecole Polytechnique de Paris (2), em 1947, Mandelbrot obteve o seu grau de mestre no Caltech (California Institute of Technology - EUA), em 1949, e o seu doutorado em Ciências Matemáticas na Université de Paris, em 1952.

Mas, afinal, o que Mandelbrot fez? $\mathrm{Na}$ verdade, até hoje se estuda a criação de Mandelbrot e se estudará cada vez mais nos próximos anos; logo não seria possível explicar em uma página de revista $o$ que ele fez, porém de forma bastante resumida e simplista, é possível dizer que ele tornou a Matemática mais bonita.

A Geometria de Fractais, criação de Mandelbrot, é especialmente útil para explicar a formação do objetos que possuem uma dimensão fracionária, por exemplo, 1,35, algo que não segue a

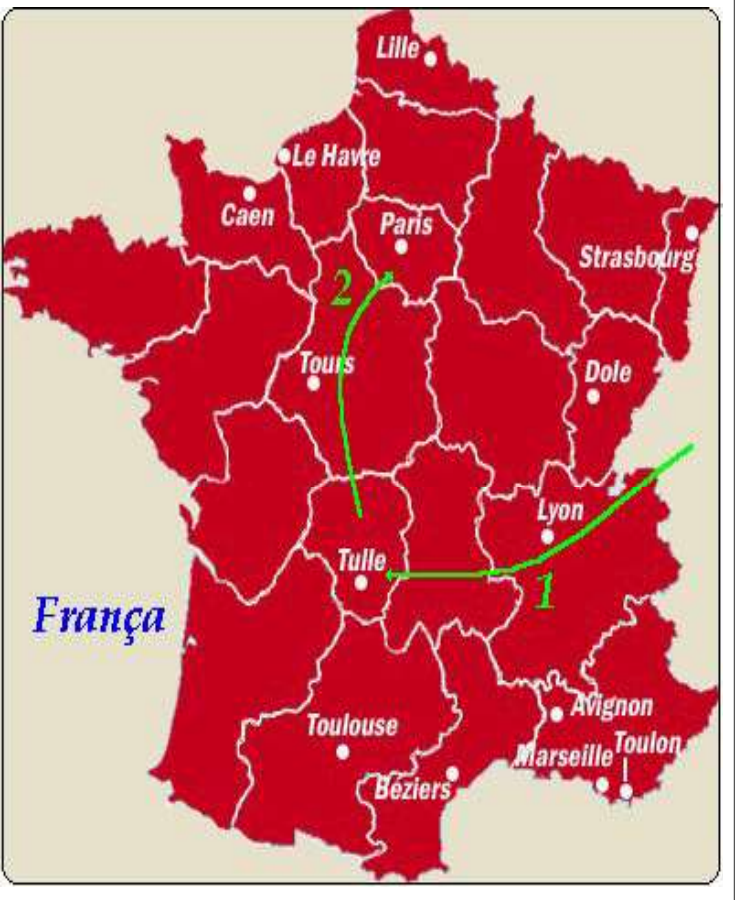

Mapa da França geometria Euclidiana. Parece estranho? Complicado? É isto mesmo, estranho e complicado. É algo tão complicado que só foi possível chegar ao seu estágio de desenvolvimento atual com o auxilio de (na época) supercomputadores. No início dos anos de 1980, Mandelbrot já trabalhava na International Business Machines Corporation, a IBM, onde utilizou os computadores da empresa para aprofundar a revolução.

E além de coisas aparentemente incompreensíveis às pessoas mais comuns, para que servem os fractais?

Os fractais não são meramente artifícios da Matemática Pura ou obras de arte sem sentido, são, na verdade, algo onde se descobrem aplicações novas a cada dia nos mais diversos ramos da ciência a das artes. Muitas pesquisas são desenvolvidas baseadas nas características dos fractais, por exemplo, a forma como a quantidade de informações é armazenada dentro do DNA talvez utilize uma estrutura fractal; órgãos como os pulmões, rins e veias talvez sejam estruturas com características fractais; a variação de preços no mercado, a forma com que grãos de areia se distribuem em uma praia, e uma infinidade de outros exemplos que utilizam os fractais para 
encontrar uma certa ordem em sistemas que aparentam ser totalmente aleatórios.

Procurando por mais respostas, o Grupo Tchê Química entrevitou Benoit B. Mandelbrot, o homem que percebeu os fractais. Veja o que ele respondeu as nossas questões:

1. What city were you born? In what year?

I was born in Warsaw (Poland), 1924.

2. Where did you finish elementary school? And high school?

I finished elementary school in Warsaw. And finished high school in Tulle (a small city in Central France)

3. What university did you concluded your graduation? What course? Did you do any post graduation course?

Ecole Polytechnique (Paris): 1947; Caltech: MS 1949;

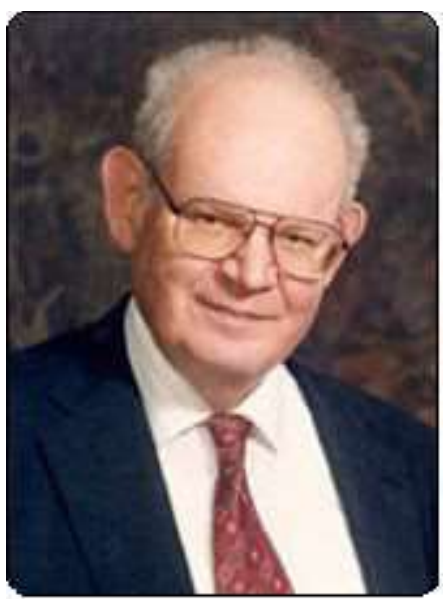

Benoit B. Mandelbrot Université de Paris: Ph.D. in Mathematical Sciences 1952.

4. In what area, specifically, were your post 7. Professor Benoît, what is, after all, the graduation studies concentrated? Why did you Fractal theory? choose this area?

Fractal geometry is the proper geometry of

The topic of my Ph.D. thesis was conceived roughness, while Euclidean geometry is the and written completely on my own, I chose a geometry of smoothness.

very unusual combination of linguistics, statistics (power-law distributions) and 8. Which fractal is the most commonly known? statistical physics. This was viewed as strange Why?

but I thought was far more interesting than the conventional topics that my teachers mentioned as possibilities. The thesis was very badly extraordinary beauty with extraordinary written, but much of its content has survived and mathematical difficulty. is now viewed as "classical."

5. What was your first job?

Junior Professor Université de Genève.

6. How did you decided to work on IBM?

While I was a post-doc with John von the earliest but most difficult and also Newmann, in Princeton, I met one of his impossible to measure experimentally. programmers. He later joined IBM and wanted me to join also. I accepted, but only for the duration of a summer. However, once at 10. Professor Mandelbrot, people say that Yorktown, I found I liked IBM better than my Newton got struck in the head by an apple and professorship in France, so I stayed. This was a realized all the gravity around us, what struck colossal gamble but an excellent decision.
9. Then, what is exactly the "fractal dimension" (originally, the Hausdorf-Besicovitch dimen sion)?

Fractal dimension is a quantitative measure of roughness. It comes in several variants, of which the Hausdorff-Besicovich dimension is

Nothing that I recall. Amusingly, the legend of Newton's apple makes concrete the 
fact that one tends to expect a theory to proceed complete dimension (1, 2 or 3), or so, that from top down, from a principle to its represent a fractal dimension, 1,85 for consequences. To the contrary, fractal geometry example?

grew from bottom to top, very slowly, over very many years.

Take coastlines; rather smooth ones have

11. Due to your European origin and the dimensions like 1.1 , more wiggly ones have beautiful shapes that fractals can be shown, is found for curves more wiggly than any several people deduce that you are a painter. coastlines on Earth.

When you finished your fractal studies did you expect this kind of reaction from the public?

15. When we integrate the fractals to the Minkowski space-time concept, is it reasonable

I do not paint myself, but am a skilled to suppose that fractionary dimensions are not amateur critic. I did not expect any strong part of Euclidian geometry and can be excluded reaction from the public but the very wide as a future possibility?

interest that my work has attracted is a delight.

12. Is there any object that is a clear example of

Yes. To give them a precise meaning, you must go beyond Euclidean geometry.

a fractal, that we can look and say: "That was what Mandelbrot was talking about"? Or do we have to study a great deal of mathematics to, through the interpretation of equations, finally be able to say that?

16. Can fractionary dimensions be described as transition stages between integer dimensions?

In general, yes, but not always.

The cauliflower's surface is fractal. It 17. Hendrik Houtahkker utilized Gaussian subdivides into small pieces, called florets; each distribution to attempt to find the behavior of which is a small version of the whole and patterns for the price of cotton, however, the itself subdivides into even smaller pieces. This curve did not adjusted to the expected Gaussian very important property is called self-similarity behavior. In which way did the fractal geometry and all fractals satisfy some strict or generalized adjusted this problem?

form of self-similarity.

Models that use fractal functions provide a mathematical model for many properties of 13. Which mathematics equations represent the pricesthat simple inspection suffices to reveal. shape that the fractals can take place in order They change discontinuously and their changes that any person that has studied some today depend on their changes in the distant mathematic will be able to understand?

The equations that represent fractals are hurricanes.

very simple. For example, the main part of the equation of the Mandelbrot set is $z . z+c$. This formula only requires five symbols! But even 18. What is the relation of the fractal geometry the most skilled mathematician could not with the work of Edward Lorenz? Do they conceivably have expected the complexity of the complement each other? Did you, in any time, set it defines. exchanged information with Edward Lorenz as you did with Hendrik Houtahkker?

14. We are used to realize only objects that I know Edward Lorenz very well. His work represent entire dimensions, like 1, 2, and 3. has introduced many beautiful shapes that are What is an object that does not represent a fractal. 
19. Is it possible to study fractals for some financial market or about which horse has a practical application (in viable time) without the better chance of winning the race?

use of computers?

Not really. Formulas that are able to

Now it has become easier but computers predict are an old, very nice, and indestructable are becoming unavoidable in almost every field. dream of humanity. But so far no one has achieved this dream.

21. Have you ever considered the possibility of using the

20. The computers evolved a lot since you fractal geometry to place bets started the fractal research. Nowadays, is it in casinos? Have you ever possible for an ordinary person to use a heard of someone who has domestic computer to make, with the proper done that?

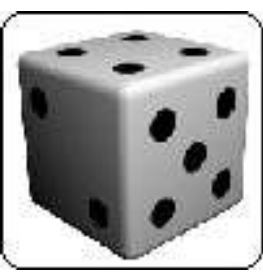
mathematic treatment $e$ utilizing an equally proper data base, predictions about the No.

22. Professor Mandelbrot, a lot of people see applications of fractal geometry in practically everything. Do you believe that this can lead other areas of mathematics to regress or do you think that mathematics, as a whole will gain benefit from the fractals?

Some degree of roughness is found everywhere, therefore fractals have innumerable practical applications. They also help in other branches of mathematics. But roughness is only one of many structures and fractals leave much work for other parts of mathematics.

23. When you started your fractals studies did you imagine that they would have so many applications? And also that just a few people would be able to interpret the possibilities offered by the fractals?

Nobody could have expected fractals to develop that far and more and more persons are using the new possibilities. The main difficulty is often not strictly speaking technical but psychological. To convince people they should try fractals has been and continues to be a struggle.

Benoit B. Mandelbrot Sterling Professor of Mathematical Sciences, Yale University Homepage: http://www.math.yale.edu/mandelbrot

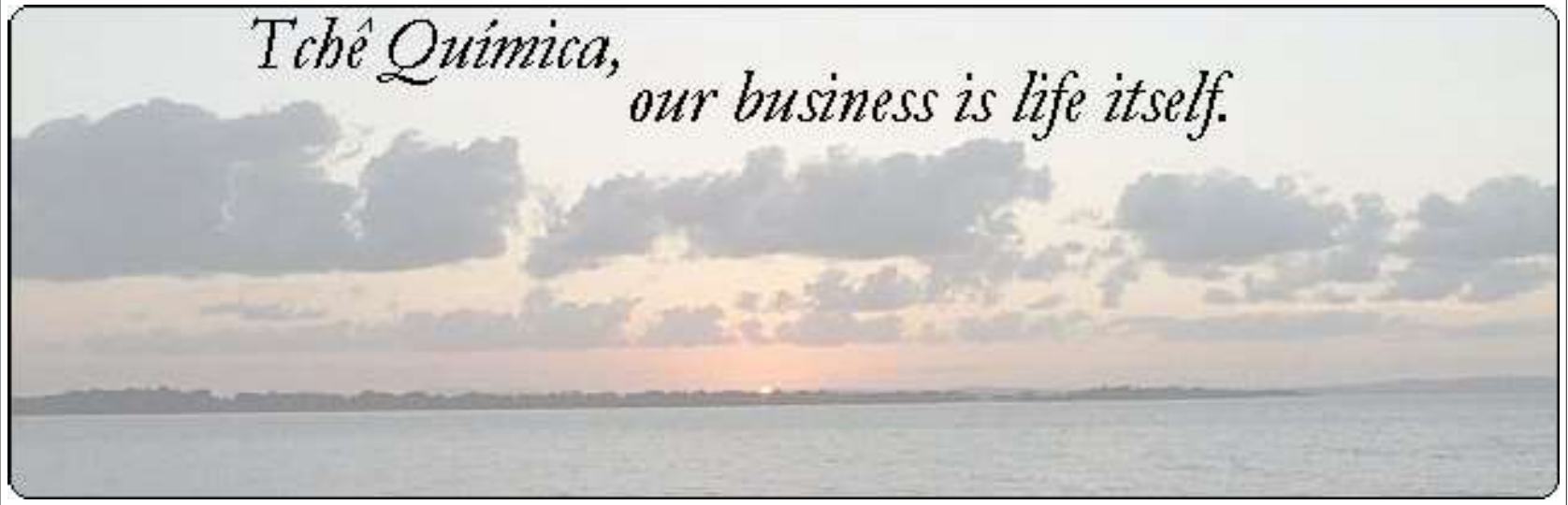

